\title{
Effect of Planting Dates and Plant Spacing on Growth and Yield Attributes of Sweet Potato [Ipomoea batatas (L.) Lam.] cv.CO-3-4
}

\author{
Nisha Kumari Meena*, R. S. Rathore and Mithlesh Kumari Meena \\ Maharana Pratap University of Agriculture and Technology, \\ Udaipur -313001, Rajasthan, India \\ *Corresponding author
}

\section{A B S T R A C T}

An experiment was carried out to study the effect of planting dates and plant spacing on growth and yield attributes of sweet potato cv.CO-3-4 at Horticulture Farm, Department of Horticulture, Rajasthan College of Agriculture, MPUAT, Udaipur during May, 2016 to

\section{Keywords}

Sweet potato, Yield, Growth, Plant spacing, Planting dates

\section{Article Info}

Accepted:

22 March 2020

Available Online:

10 April 2020 November, 2016. The experiment was comprised of four levels of plant spacing on four different dates with Factorial Randomized Block Design. The results revealed that the vegetative growth and yield attributes are significantly influenced by various level of spacing. The minimum time taken for $50 \%$ sprouting (11.58 days), maximum vine length $(195.92 \mathrm{~cm})$, leaves per vine $(91.74)$, tuberous per plant $(5.21)$, tuber length $(18.86 \mathrm{~cm})$, tuber diameter $(9.73 \mathrm{~cm})$ and yield per ha $(29.97 \mathrm{t}$ per ha) were recorded in wider spacing $40 \mathrm{x} 40 \mathrm{~cm}$ (treatment $\mathrm{P}_{4}$ ). The planting dates also influenced vegetative growth and yield parameter of sweet potato. The minimum time taken for 50 per cent sprouting (11.75), maximum vine length (184.58), leaves per vine (88.50), tuberous per plant (5.08), tuber length $(17.39 \mathrm{~cm})$, tuber diameter $(8.85 \mathrm{~cm})$ and yield $\left(30.50 \mathrm{t} \mathrm{ha}^{-1}\right)$ were recorded in $10^{\text {th }}$ June of planting (treatment $\mathrm{S}_{3}$ ). The interaction of planting dates and plant spacing also significantly influenced on sweet potato. The minimum time taken for 50 per cent sprouting, maximum vine length $(226.67 \mathrm{~cm})$, leaves per vine $(100.33)$, tubers per vine (6.33), tuber length $(23.00 \mathrm{~cm})$, tuber diameter $(10.43 \mathrm{~cm})$ and yield $\left(34.37 \mathrm{t} \mathrm{ha}^{-1}\right)$ were recorded in treatment $\mathrm{P}_{4} \mathrm{~S}_{3}\left(40 \times 40 \mathrm{~cm}\right.$ and $10^{\text {th }}$ June $)$.

\section{Introduction}

Sweet potato [Ipomoea batatas (L.) Lam.] belongs to the family Convolvulaceae and has chromosome number $(2 \mathrm{n}=90)$. It is originated from Central America and spread to other parts of the world. The main growing states are Bihar, Orissa, Uttar Pradesh, Madhya Pradesh, Maharashtra, Karnataka and
Rajasthan. Sweet potato occupied an area of 790 hectares with production of 224 tonnes in Rajasthan (Saxena et al., 12).

In Rajasthan sweet potato are mainly grown in Udaipur, Chittorgarh, Jhalawar, Sikar, Bhilwara, Jaipur and Nagour district. It is a perennial crop usually grown as an annual and a starchy staple food crop in tropical, sub- 
tropical and frost-free temperate climatic zones of the world and historically played an important role in the quest for food and the struggle for human survival in several countries. It is a warm-season crop and grows best in abundant sunshine, temperatures above $24^{\circ} \mathrm{C}$, sandy loam soil and a welldistributed rainfall of $850-900 \mathrm{~mm}$ per annum. It matures in 3-4 months duration depending on the variety (Anonymous,3). It is a very nutritive vegetable, producing substantially high edible energy per hectare per day compared to rice, wheat, maize and cassava. It contains starch (12.7 g), sugar (4.2 g), vitamin A $(709 \mu \mathrm{g})$ and protein $(1.6 \mathrm{~g})$ per $100 \mathrm{~g}$ of edible part (USDA, 2013). In spite of its importance as a food and vegetable, very little attention has been given on improved cultural practices i.e. planting dates and spacing. The yield of tuberous roots per plant increases with the increase in plant spacing (Onwueme, 10; Mannan, 9). Wider plant spacing not only leads to excessive vegetative growth but also accelerates evaporation loss of water from the bare ground. On the other hand, the struggle for existence increases with increasing plant population because of severe competition for light, water and nutrients at high plant population. The correct date of planting leads to high vegetative growth and yield of crop. It is therefore appear logical that a adequate spacing may probably leads to greater crop yield through rapid attainment of ground cover for better interception of solar radiation and hence an increases in photosynthetic ability of crop. Scanty research works are available on the spacing and planting dates in context of Rajasthan. Therefore, it is need to find out optimum time for higher yield.

\section{Materials and Methods}

The present study was conducted at Horticulture Farm, Department of Horticulture, Rajasthan College of
Agriculture, Maharana Pratap university of Agriculture and Technology, Udaipur during May, 2016 to November, 2016. The experiment was comprised of four levels of plant spacing viz., $30 \times 20 \mathrm{~cm}\left(\mathrm{P}_{1}\right), 30 \times 30 \mathrm{~cm}$ $\left(\mathrm{P}_{2}\right), 40 \times 30 \mathrm{~cm}\left(\mathrm{P}_{3}\right)$ and $40 \times 40 \mathrm{~cm}\left(\mathrm{P}_{4}\right)$ with four different dates i.e. $20^{\text {th }}$ May $\left(\mathrm{S}_{1}\right), 30^{\text {th }}$ May $\left(\mathrm{S}_{2}\right), 10^{\text {th }}$ June $\left(\mathrm{S}_{3}\right)$ and $20^{\text {th }}$ June $\left(\mathrm{S}_{4}\right)$. The experiment was laid out in factorial randomized block design with three replications. Fertilizers were applied @ $50 \mathrm{~kg}$ $\mathrm{N}, 60 \mathrm{~kg} \mathrm{P}_{2} \mathrm{O}_{5}$ and $50 \mathrm{~kg} \mathrm{~K}_{2} \mathrm{O}$ along with 3 tonnes of farmyard manure per hectare to meet the nutritional requirement of crop. The soil of experimental plot was clay loam with $\mathrm{pH} 7.4$, EC $0.54 \mathrm{dS} / \mathrm{m}$, organic carbon $0.47 \%$ and available N,P and $\mathrm{K}$ as 186.5, 26.5 and $252 \mathrm{~kg} / \mathrm{ha}$, respectively. The experiment site falls under agro-climatic Zone IV a i.e. "South-humid Southern Plain and Aravalli Hills" of Rajasthan at altitude of 582.17 meter above mean sea level, $24^{\circ} 35^{\prime}$ latitude and $74^{\circ} 42^{\prime} \mathrm{E}$ longitude. The average rainfall of this tract ranges from $592.5 \mathrm{~mm}$ to $620 \mathrm{~mm}$ per year.

The observation on vegetative growth characteristics viz., time taken for 50 per cent sprouting, vine length and leaves per vine and yield parameters viz., number of tubers per vine, tuber length, tuber diameter and yield were recorded as standard methods and statistically analysed.

\section{Results and Discussion}

\section{Effect of plant spacing on growth parameters}

A perusal of data in Table 1 indicated that various level of plant spacing significantly affected the time taken for $50 \%$ sprouting, vine length and leaves per vine of sweet potato. The widest plant spacing $(40 \times 40 \mathrm{~cm})$ took minimum time for $50 \%$ sprouting (11.58 days), recorded maximum vine length (195.92 
$\mathrm{cm})$ and leaves per plant (91.74). Whereas, maximum time taken for $50 \%$ sprouting (13.04), minimum vine length $(135.33 \mathrm{~cm})$ and minimum leaves per vine (76.00) were recorded in closer spacing in treatment $\mathrm{P}_{1}(30$ $\mathrm{x} 20 \mathrm{~cm}$ ).It might be due to that at widest plant spacing have less competition both for nutrient and all other resource of environment then narrow spacing and hence instead of vertical growth horizontally and produced more vine length and leaves per plant. The production of more number of leaves per plant at the wider spacing might be attributed to the more efficient use of available growth resources like nutrients, water and light energy, that would favour more photosynthetic rate and accumulation of carbohydrate for all growing points as compared to the closest spacing.

The decrease in vine length in response to closer plant spacing might be ascribed to stiffer inter plant competition for growth factors such as soil moisture, nutrients and light etc. The present finding was also supported with Yadav et al., (15), Mahender et al., (8) and Woelore et al., (14) in Zingiber officinale.

\section{Effect of planting dates on growth parameters}

The data presented in Table 1 revealed that planting dates influence significantly the time taken to $50 \%$ sprouting, vine length and leaves per vine in sweet potato. The minimum time taken to $50 \%$ sprouting (11.75 days), maximum vine length $(184.52 \mathrm{~cm})$ and leaves per plant (88.50) were recorded in $10^{\text {th }}$ June planting of sweet potato (treatment $\mathrm{S}_{3}$ ). Whereas, minimum vine length $(159.50 \mathrm{~cm})$ was recorded in treatment $\mathrm{S}_{1}\left(20^{\text {th }}\right.$ May), leaves per vine (78.33) was recorded in treatment $S_{2}\left(30^{\text {th }}\right.$ May). The vine length and leaves per vine were gradually decreased with the delay in planting dates (Islam et al., 6 in garlic).The highest sprouting in low days might be due to congenial weather conditions, favourable soil temperature. The result is supported by Alloli, (2) in sweet potato and Yadav et al., (15) in Zingiber officinale.

Interaction effect of planting dates and plant spacing on growth parameters

The data revealed (Table 1) that the interaction effect of planting dates and spacing with respect to minimum time taken for $50 \%$ sprouting (9.50), maximum vine length $(226.67 \mathrm{~cm})$ and leaves per vine (100.33) were recorded in treatment combination $\mathrm{P}_{4} \mathrm{~S}_{3}\left(40 \times 40 \mathrm{~cm}\right.$ and $10^{\text {th }}$ June $)$. Whereas, minimum vine length $(116.67 \mathrm{~cm})$ was recorded in treatment combination $\mathrm{P}_{1} \mathrm{~S}_{1}$ (30 x $20 \mathrm{~cm}$ and $20^{\text {th }}$ May), minimum leaves per vine (72.67) was observed in treatment combination $\mathrm{P}_{1} \mathrm{~S}_{2}\left(30 \times 20 \mathrm{~cm}\right.$ and $30^{\text {th }}$ May).The increase in growth parameter might due to the temperature and relative humidity wasfavourable during June and widest spacing increased growth parameter due to less competition for water and nutrients between plants. These similar finding was given by Yadav et al. (15)Zingiber officinale.

\section{Effect of plant spacing on yield parameters}

The data presented in Table 2 revealed that maximum tubers per plant (5.21), tuber length $(18.86 \mathrm{~cm})$, tuber diameter $(9.73 \mathrm{~cm})$ and yield $\left(29.97 \mathrm{t} \mathrm{ha}^{-1}\right)$ were recorded in treatment $\mathrm{P}_{4}(40 \times 40 \mathrm{~cm})$ i.e. at wider spacing. while, minimum tubers per plant (3.36), tuber length $(13.19 \mathrm{~cm})$, tuber diameter $(5.63 \mathrm{~cm})$ and yield $\left(22.74 \mathrm{t} \mathrm{ha}^{-1}\right)$ were recorded in treatment $\mathrm{P}_{1}(30 \times 20 \mathrm{~cm})$ i.e. in closer spacing. This result is agreement with that of Beleha (4) reported that increasing plant population decreased the tuberous per plant in sweet potato. 
Table.1 Effect of plant spacing, planting dates and their interaction on growth parameters of sweet potato

\begin{tabular}{|c|c|c|c|}
\hline Treatments & $\begin{array}{c}\text { Time taken for } 50 \% \\
\text { sprouting (days) }\end{array}$ & Vine length (cm) & Leaves /vine \\
\hline \multicolumn{4}{|l|}{ Plant spacing } \\
\hline$P_{1}(30 \times 20 \mathrm{~cm})$ & 13.04 & 135.33 & 76.00 \\
\hline$P_{2}(30 \times 30 \mathrm{~cm})$ & 12.71 & 168.67 & 79.16 \\
\hline$P_{3}(40 \times 30 \mathrm{~cm})$ & 12.83 & 189.92 & 87.66 \\
\hline$P_{4}(40 \times 40 \mathrm{~cm})$ & 11.58 & 195.92 & 91.74 \\
\hline SEm \pm & 0.24 & 2.87 & 1.49 \\
\hline $\mathrm{CD}(\mathrm{p}=\mathbf{0 . 0 5})$ & 0.68 & 8.30 & 4.30 \\
\hline \multicolumn{4}{|l|}{ Planting dates } \\
\hline$S_{1}\left(20^{\text {th }}\right.$ May $)$ & 12.08 & 159.50 & 80.33 \\
\hline$S_{2}\left(3^{\text {th }}\right.$ May $)$ & 12.79 & 163.75 & 78.33 \\
\hline$S_{3}\left(10^{\text {th }}\right.$ June $)$ & 11.75 & 184.58 & 88.50 \\
\hline $\mathrm{S}_{4}\left(20^{\text {th }}\right.$ June $)$ & 13.54 & 182.00 & 87.42 \\
\hline SEm \pm & 0.24 & 2.87 & 1.49 \\
\hline $\mathrm{CD}(\mathrm{p}=\mathbf{0 . 0 5})$ & 0.68 & 8.30 & 4.31 \\
\hline \multicolumn{4}{|l|}{ Interaction (PXS) } \\
\hline $\mathbf{P}_{1} \mathbf{S}_{1}$ & 11.67 & 116.67 & 73.33 \\
\hline $\mathbf{P}_{1} \mathbf{S}_{2}$ & 13.00 & 125.00 & 72.67 \\
\hline $\mathbf{P}_{1} \mathbf{S}_{3}$ & 14.00 & 141.67 & 75.00 \\
\hline $\mathbf{P}_{1} \mathbf{S}_{4}$ & 13.50 & 158.00 & 83.00 \\
\hline $\mathbf{P}_{2} \mathbf{S}_{1}$ & 12.17 & 163.33 & 72.68 \\
\hline $\mathbf{P}_{2} \mathbf{S}_{2}$ & 14.10 & 164.67 & 74.00 \\
\hline $\mathbf{P}_{2} \mathbf{S}_{3}$ & 11.67 & 180.00 & 84.33 \\
\hline $\mathbf{P}_{2} \mathbf{S}_{4}$ & 13.00 & 166.67 & 85.67 \\
\hline $\mathbf{P}_{3} \mathbf{S}_{1}$ & 13.00 & 182.33 & 85.33 \\
\hline $\mathbf{P}_{3} \mathbf{S}_{2}$ & 12.50 & 184.00 & 80.67 \\
\hline $\mathbf{P}_{3} \mathbf{S}_{3}$ & 11.83 & 190.00 & 94.33 \\
\hline $\mathbf{P}_{3} \mathbf{S}_{4}$ & 14.00 & 203.33 & 90.33 \\
\hline $\mathbf{P}_{4} \mathbf{S}_{1}$ & 11.50 & 175.67 & 90.00 \\
\hline $\mathbf{P}_{4} \mathbf{S}_{2}$ & 11.67 & 181.33 & 86.00 \\
\hline $\mathbf{P}_{4} \mathbf{S}_{3}$ & 9.50 & 226.67 & 100.33 \\
\hline $\mathbf{P}_{4} \mathbf{S}_{4}$ & 13.67 & 200.00 & 90.67 \\
\hline SEm \pm & 0.47 & 5.75 & 2.98 \\
\hline $\mathrm{CD}(\mathrm{p}=\mathbf{0 . 0 5})$ & NS & 17.25 & 8.94 \\
\hline C.V. \% & 6.50 & 5.77 & 6.18 \\
\hline
\end{tabular}


Table.2 Effect of plant spacing, planting dates and their interaction on yield parameters of sweet potato

\begin{tabular}{|c|c|c|c|c|}
\hline Treatments & No. of tubers/vine & $\begin{array}{l}\text { Tuber length } \\
\text { (cm) }\end{array}$ & Tuber diameter $(\mathrm{cm})$ & Yield ha ${ }^{-1}$ \\
\hline \multicolumn{5}{|l|}{ Plant spacing } \\
\hline$P_{1}(30 \times 20 \mathrm{~cm})$ & 3.63 & 13.19 & 5.63 & 22.74 \\
\hline$P_{2}(30 \times 30 \mathrm{~cm})$ & 4.29 & 14.47 & 7.07 & 24.10 \\
\hline$P_{3}(40 \times 30 \mathrm{~cm})$ & 5.13 & 17.61 & 9.30 & 26.19 \\
\hline$P_{4}(40 \times 40 \mathrm{~cm})$ & 5.21 & 18.86 & 9.73 & 29.97 \\
\hline SEm \pm & 0.10 & 0.45 & 0.15 & 0.37 \\
\hline $\mathrm{CD}(\mathrm{p}=\mathbf{0 . 0 5})$ & 0.30 & 1.31 & 0.45 & 1.06 \\
\hline \multicolumn{5}{|l|}{ Planting dates } \\
\hline$S_{1}\left(20^{\text {th }}\right.$ May $)$ & 4.00 & 14.47 & 6.69 & 21.36 \\
\hline$S_{2}\left(3^{\text {th }}\right.$ May $)$ & 4.38 & 15.53 & 7.43 & 23.51 \\
\hline$S_{3}\left(10^{\text {th }}\right.$ June $)$ & 5.08 & 17.39 & 8.85 & 30.50 \\
\hline$S_{4}\left(20^{\text {th }}\right.$ June $)$ & 4.79 & 16.75 & 8.77 & 27.63 \\
\hline $\operatorname{SEm} \pm$ & 0.10 & 0.45 & 0.15 & 0.37 \\
\hline$C D(p=0.05)$ & 0.30 & 1.31 & 0.45 & 1.06 \\
\hline \multicolumn{5}{|l|}{ Interaction (PXS) } \\
\hline $\mathbf{P}_{1} \mathbf{S}_{1}$ & 3.33 & 12.60 & 3.67 & 18.90 \\
\hline $\mathbf{P}_{1} \mathbf{S}_{2}$ & 3.50 & 12.80 & 4.83 & 20.90 \\
\hline $\mathbf{P}_{1} \mathbf{S}_{3}$ & 3.67 & 13.47 & 6.70 & 26.40 \\
\hline $\mathbf{P}_{1} \mathbf{S}_{4}$ & 4.00 & 13.90 & 7.33 & 24.75 \\
\hline $\mathbf{P}_{2} \mathbf{S}_{1}$ & 3.50 & 12.90 & 5.50 & 19.42 \\
\hline $\mathbf{P}_{2} \mathbf{S}_{2}$ & 4.00 & 14.17 & 6.61 & 22.00 \\
\hline $\mathbf{P}_{2} \mathbf{S}_{3}$ & 4.50 & 15.07 & 7.92 & 29.32 \\
\hline $\mathbf{P}_{2} \mathbf{S}_{4}$ & 5.17 & 15.73 & 8.25 & 25.65 \\
\hline $\mathbf{P}_{3} \mathbf{S}_{1}$ & 4.67 & 16.57 & 8.37 & 21.70 \\
\hline $\mathbf{P}_{3} \mathbf{S}_{2}$ & 5.33 & 17.40 & 8.84 & 22.27 \\
\hline $\mathbf{P}_{3} \mathbf{S}_{3}$ & 5.83 & 18.00 & 10.33 & 31.90 \\
\hline $\mathbf{P}_{3} \mathbf{S}_{4}$ & 4.67 & 18.47 & 9.67 & 28.87 \\
\hline $\mathbf{P}_{4} \mathbf{S}_{1}$ & 4.50 & 15.80 & 9.22 & 25.40 \\
\hline $\mathbf{P}_{4} \mathbf{S}_{2}$ & 4.67 & 17.73 & 9.44 & 28.87 \\
\hline $\mathbf{P}_{4} \mathbf{S}_{3}$ & 6.33 & 23.00 & 10.43 & 34.37 \\
\hline $\mathbf{P}_{4} \mathbf{S}_{4}$ & 5.33 & 18.90 & 9.83 & 31.25 \\
\hline SEm \pm & 0.21 & 0.91 & 0.31 & 0.73 \\
\hline $\mathrm{CD}(\mathrm{p}=\mathbf{0 . 0 5})$ & 0.60 & 2.73 & 0.93 & 2.19 \\
\hline C.V. \% & 7.88 & 9.78 & 6.74 & 4.93 \\
\hline
\end{tabular}


At wider spacing better plant exposure for high radiation interception might have increased the photosynthetic efficiency of the plant. The present finding was also conformity by Zamil et al., (18), Zaeg et al., (17) and Gulluoglu and Arioglu (5) in Solanum tuberosum. Further the number of tubers produced per stem is less in higher densities as share of the light and food is reduced resulting in reduced number of tuberous root as reported by Razaei and Soltani (11).

\section{Effect of planting dates on yield parameters}

The data revealed that effect of planting dates on yield attribute was observed significant effect. The perusal of data (Table 2) revealed that maximum tubers per plant (5.08), tuber length $(17.39 \mathrm{~cm})$,tuber diameter $(8.85 \mathrm{~cm})$ and yield (30 $50 \mathrm{t} \mathrm{ha}^{-1}$ ) were recorded in treatment $\mathrm{S}_{3}\left(10^{\text {th }}\right.$ June).Whereas, minimum tubers per plant (4.00), tuber length (14.47 $\mathrm{cm})$, tuber diameter $(6.97 \mathrm{~cm})$ and yield $\left(21.36 \mathrm{t} \mathrm{ha}^{-1}\right)$ were recorded in treatment $\mathrm{S}_{1}$ ( $20^{\text {th }}$ May). It might be due to favourable climatic condition, soil and atmospheric temperature during June planting. Earlier in month of May the soil and atmospheric temperature was higher and this affect the growth of sweet potato. This finding was supported by Alloli et al., (2) in sweet potato, Yenagi et al., (16) in Solanum tuberosum and Mahender et al., (8) in Zingiber officinale.

Interaction effect of planting dates and spacing on yield parameters

The data indicated in table 2 that the maximum tubers per plant (6.33), tuber length $(23.00 \mathrm{~cm})$, tuber diameter $(10.43 \mathrm{~cm})$ and yield (34.37 $\left.\mathrm{t} \mathrm{ha}^{-1}\right)$ were recorded in treatment combination $\mathrm{P}_{4} \mathrm{~S}_{3}\left(40 \times 40 \mathrm{~cm}\right.$ and $10^{\text {th }}$ June $)$. Whereas, the minimum tubers per plant (3.33), tuber length $(12.60 \mathrm{~cm})$, tuber diameter $(3.67 \mathrm{~cm})$ and yield $\left(18.90 \mathrm{t} \mathrm{ha}^{-1}\right)$ were recorded in treatment combination $\mathrm{P}_{1} \mathrm{~S}_{1}$ (30 X $20 \mathrm{~cm}$ and $20^{\text {th }}$ May). This might be due to June planting and wider spacing, the growth period passes through favourable temperature, relative humidity and good moisture conditions, which improves the tubers per plant, tuber length, tuber diameter and yield of sweet potato. The similar findings were also recorded by Kushwah et al., (7), Alloli et al., (2) in sweet potato and Yadav et al., (13) in Zingiber officinale.

On the basis of experimentation it is concluded that the vegetative growth characteristics viz. time taken for $50 \%$ sprouting, vine length, leaves per vine and yield attributes viz. number of tubers per plant, tuber length, tuber diameter and yield were recorded superior in spacing $40 \mathrm{x} 40 \mathrm{~cm}$ (treatment $\mathrm{P}_{4}$ ) and planting date of $10^{\text {th }}$ June (treatment $\mathrm{S}_{3}$ ). The treatment combination of $\mathrm{P}_{4} \mathrm{~S}_{3}\left(40 \times 40 \mathrm{~cm}\right.$ and $10^{\text {th }}$ June) was superior for vegetative and yield attributes of sweet potato.

\section{References}

1. Abdissa, T., Chali, A., Tolessa, K., Tadese, K. and Awas, G. 2011. Yield and yield component of sweet potato as influenced by plant density in Adami Tulu Jido Kombolcha district, Central Rift Valley of Ethiopia. American Journal of Experimental Agriculture, 1(2): 40-48.

2. Allolli, T.B., Athani, S.I. and Imamsaheb, S.J. 2011. Effect of different dates of planting on growth and yield performance of sweet potato (Ipomoea batatas L.) under Dharwad condition. Asian J. Hort., 6 (2): 303-305.

3. Anonymous. 2003. Treasure for the poor in sweet potato. CIP (International Potato Centre) Lime Peru. Pp. 25.

4. Belehu, T. 2003. Effect of planting density 
and cultivar on yield and yield components of sweet potato [Ipomoea batatas L. (Lam.)] grown in Hawassa and Melkassa Agricultural Research Centers of Ethiopia. University of Pretoria etd. p. 213.

5.Gulluoglu, L. and Arioglu, H. 2009. Effects of seed size and in-row spacing on the growth and yield of early potato in a Mediterranean type environment in Turkey. African Journal of Agricultural Research, 3(3): 1062-1070.

6. Islam, M. A., Reza, M. H., Kamal, S. M. A. H. M., Wazed, M. A. and Islam, K. M. 2008. Effect of planting dates and gibberellic acid on the growth and yield of garlic. A Scientific Journal of Krishi Foundation, The Agriculturists, 6 (1\&2): 132-139.

7.Kushwah, S.S., Dwivedi, Y.C. and Jain, P.K. 2011. Effect of time of planting on growth, yield and economics of sweet potato under rainfed conditions. Journal of Root Crops, 37 (2): 189-191.

8. Mahender, B., Reddy P. S. S., Sivram, G. T., Balakrishna, M. and Prathap, B. 2015. Effect of seed rhizome size and plant spacing on growth, yield and quality of ginger (Zingiber officinale Rosc.) under coconut cropping system. Plant Archives, 15 (2): 769-774.

9. Mannan, M.A.1984. Effect of plant spacing on the yield contributing characters and yield of sweet potato, Bangladesh Hort., 12 (1): 57-58.

10. Onwueme, I.C. 1978. The Tropical Tuber Crops. John Wiley and Sons, Chichesten, pp: 167-194.

11. Rezaei, A. and Soltani, A. 1996. Potato farming (translated). Press University of Mashhad, Iran, p.132.

12. Saxena, M., Battacharya, S. and Malhotra, S.K. 2016. Area and production of sweet potato. In: Horticulture Statistics at a Glance 2015, Oxford University Press, New Delhi, pp.210.

13. USDA. Data base. 2013. National nutrient data base for standard reference release.

14. Woelore, W. M., Tesfaye, B. and Gedebo, A. 2016. Effect of sett size and spacing on the growth and yield of ginger (Zingiber officinale Rosc.) at Areka, Wolaita, Souther Ethiopia. Journal of Natural Science Research, 6 (19): 1-23.

15.Yadav, A.R., Nawale, R.N., Korake, G.N. and Khandekar, R.G. 2013. Effect of dates of planting and spacing on growth and yield characteristics of ginger (Zingiber officinale Ros.) var. IISR Mahima. Journal of Spices and Aromatic Crops, 22 (2): 209-214.

16.Yenagi, B.S., Meli, S.S. and Angadi, S.S. 2004. Effect of row spacing, planting date and nitrogen level on tuber grade, yield and economics of potato. Karnataka J. Agri.Sci., 17 (2): 220-223.

17.Zaeg, P.V., Demagante, A. L. and Ewing, E. E. 1990. Influenced of plant spacing on potato (Solanum tuberosum L.) morphology, growth and yield under two contrasting environments. Potato Research, 33(1): 313-323.

18. Zamil, M. F., Raman, M. M., Rabbani, M. G. and Khatun, T. 2010. Combined effect of nitrogen and plant spacing on growth and yield of potato with economic performance Bangladesh Research Journal, 3 (3): 1062-1070.

\section{How to cite this article:}

Nisha Kumari Meena, R. S. Rathore and Mithlesh Kumari Meena. 2020. Effect of Planting Dates and Plant Spacing on Growth and Yield Attributes of Sweet Potato [Ipomoea batatas (L.) Lam.] cv.CO-3-4. Int.J.Curr.Microbiol.App.Sci. 9(04): 2602-2608. doi: https://doi.org/10.20546/ijcmas.2020.904.311 